\title{
Effect of STAT1, OLR1, CSN1S1, CSN1S2, and DGAT1 genes on milk yield and composition traits of Holstein breed
}

\author{
Sena Ardicli ${ }^{1}$ (ID), Bahadir Soyudal', Hale Samli ${ }^{1}$ (iD, Deniz Dincel ${ }^{1}$ (iD), Faruk Balci ${ }^{1 *}$ \\ ${ }^{1}$ Uludag University, Faculty of Veterinary Medicine, Department of Genetics, Nilufer, Bursa, Turkey.
}

\begin{abstract}
The objectives of the study were to evaluate allelic frequencies and test the association between STAT1, OLR1, CSN1S1, CSN1S2, and DGAT1 gene polymorphisms and milk production traits including lactation milk yield, 305 days milk yield, days before peak milk production, and peak milk yield. In addition, samples of milk were analysed for fat, protein, lactose, and total solid contents. A total of 168 purebred Holstein-Fresian cows were genotyped using polymerase chain reaction and restriction fragment length polymorphism methods. Statistical analysis was carried out using least square methods of the general linear model procedure. Significant differences were found between genotypes of the CSN1S2 locus in relation to milk protein content. In addition, $D G A T 1$ was significantly associated with peak milk production. These results suggested that CSN1S2 and DGAT1 markers may be evaluated to achieve various commercial goals in dairy cattle production.
\end{abstract}

Key Words: cattle, dairy cow, milk composition, polymorphism

\section{Introduction}

The trend of improving dairy cattle breeding programs has gradually changed from traditional phenotypical selection methods to genotypic selection by utilising molecular markers. Identifying genes underlying the genetic variability of selected economically important traits is a major focus of dairy cattle genomics, and a large number of candidate genes have been potentially associated with milk yield and quality (Rychtáŕová et al., 2014). Candidate genes related to milk production traits, which are polygenically inherited, may be found in pathways of fat synthesis and metabolism. Single nucleotide polymorphisms (SNP) in the signal transducer and activator of transcription (STAT1), oxidised low-density lipoprotein receptor (OLR1), alpha $_{\mathrm{S} 1}$-casein (CSN1S1), alpha $\mathrm{S}_{\mathrm{S}}$-casein (CSN1S2), and diacylglycerol acyltransferase 1 (DGATI) genes have been shown to affect bovine milk production and composition traits in different cattle populations (Kucerova et al., 2006; Khatib et al., 2007; Schennink et al., 2007; Rychtářová et al., 2014).

Received: September 23, 2017

Accepted: May 23, 2018

*Corresponding author: fbalci@uludag.edu.tr

Copyright (C) 2018 Sociedade Brasileira de Zootecnia. This is an Open Access article distributed under the terms of the Creative Commons Attribution License (http://creativecommons.org/licenses/by/4.0/), which permits unrestricted use, distribution, and reproduction in any medium, provided the original work is properly cited.
STAT1 gene is located on chromosome 2 between 60 and $63 \mathrm{cM}$ interval (Band et al., 2000) and is regulated during mammary gland development (Khatib et al., 2009). STAT1 is associated with improved milk yield, composition, and production traits (Chu and Zan, 2009; Khatib et al., 2009; Rychtáŕová et al., 2014). OLR1 gene encodes surface receptors of vascular endothelial cells and degrades the oxidised forms of low-density lipoproteins (Mehta and Li, 2002; Khatib et al., 2006). The oxidised lipids are known to impair glucose metabolism and influence lipid metabolism in liver and mammary glands (Ringseis et al., 2007; Liao et al., 2008). OLRI gene is located in the interval of 106 to $108 \mathrm{cM}$ of bovine chromosome 5, in which the functional and positional genes related to fatty acid contents in milk are localised. Results of previous whole-genome scan studies suggested OLR1 as a candidate gene affecting milk composition traits (Khatib et al., 2006). CSN1S1 and CSN1S2 genes belong to the casein $(C N)$ gene family, which is situated on bovine chromosome 6 . These genes are relevant in relation to milk production parameters and milk protein quality (Kucerova et al., 2006; Ibeagha-Awemu et al., 2007). CSN1S1 codes for $\alpha_{\mathrm{S} 1}-\mathrm{CN}$; the most frequent alleles in this gene are $\mathrm{B}$ and $\mathrm{C}$, and allele A occurs occasionally (Boettcher et al., 2004; Kucerova et al., 2006). CSN1S2 codes for $\alpha_{\mathrm{S} 2}-\mathrm{CN}$, which constitutes up to $10 \%$ of the bovine $\mathrm{CN}$ fraction and exists in two major forms and several minor variants including $\mathrm{B}, \mathrm{C}$, and $\mathrm{D}$. Variant $\mathrm{A}$, also known as the reference protein form $(\mathrm{CSN} 1 \mathrm{~S} 2 * \mathrm{~A})$, is 
the most frequently observed variant in all breeds, whereas variants $\mathrm{B}$ and $\mathrm{C}$ are specific to zebu and yaks, respectively (Grosclaude et al., 1979; Ibeagha-Awemu et al., 2007). In addition, variant $\mathrm{D}$ is relevant in some European and African breeds (Ibeagha-Awemu et al., 2007). DGAT1 gene, located on chromosome 14, encodes the DGAT1 enzyme, which catalyses the final step in triglyceride synthesis (Kong et al., 2007; Thaller et al., 2003a). A nonconservative lysine-to-alanine substitution (p.Lys232Ala) in this gene has been proven to significantly influence milk components (Banos et al., 2008; Hradecká et al., 2008; Cerit et al., 2014) and intramuscular fat content (Thaller et al., 2003b; Li et al., 2013; Tait et al., 2014) in different cattle breeds. However, studies on various cattle populations could not substantiate a consistent association between DGAT1 variants and fertility traits (Kaupe et al., 2007; Oikonomou et al., 2009; Berry et al., 2010; Rychtářová et al., 2014).

The cattle population in Turkey is about 16 million. Within this population, dairy cattle plays an important role in the animal production sector and Turkish economy. In 2017, approximately 20.7 million tonnes of milk were produced from 28.5 million dairy animals, including 5.9 million cattle, 17.5 million sheep, 4.9 million goats, and 69,497 water buffaloes. Of this production, 18.8 million tonnes (approximately $91 \%$ of total) were obtained from cows (Turkish Statistical Institute, 2018). Holstein comprises by far the most common cattle breed in Turkish dairy cattle industry with approximately 6.5 millions purebreds. Despite high number of milking cows, average milk yield per cow $(3.143 \mathrm{~kg})$ remains very low compared with those of developed countries (Turkish Statistical Institute, 2018). Hence, there is still room for improvements in national milk production of Turkey.

Much research evaluating the association between milk production traits and genetic markers used in this study has been conducted and has revealed inconsistent results in various cattle populations (Kucerova et al., 2006; Khatib et al., 2009; Rychtáŕová et al., 2014). Milk production traits are under the control of polygenic inheritance, and the phenotypic expression of these traits is highly variable among breeds and even between different populations of the same breed (Braunschweig et al., 2000; Boettcher et al., 2004). Hence, focusing on novel associations and characterisation of genomic regions related to milk production traits is highly relevant. Therefore, the objective of this study was to determine allele and genotype frequencies of the STAT1, OLR1, CSN1S1, CSN1S2, and $D G A T 1$ genes and evaluate their relation to milk production parameters.

\section{Material and Methods}

The study was carried out from March 5, 2012 to December 31, 2013 under commercial cattle farm conditions. The farm was located in Karacabey, which is a district of Bursa province in the Marmara Region of Turkey (40 $15^{\prime} 09.5^{\prime \prime} \mathrm{N}$ and $\left.28^{\circ} 17^{\prime} 59.9^{\prime \prime} \mathrm{E}\right)$. Maximum and minimum ambient air temperatures $\left({ }^{\circ} \mathrm{C}\right)$ in the farm area during the period of the study were 21.6 and 9.9 in autumn, 10.6 and 2.3 in winter, 18.9 and 7.4 in spring, and 30.1 and 16.9 in summer; relative humidity percentages (\%) were 69.6, 71.3, 67.1, and 59.6; and total precipitation amounts $(\mathrm{mm})$ were $68.3,84.1,57.6$, and 23.4 in the same seasons, respectively.

All animals were recorded to the Pedigree Project of the Turkish Ministry of Food, Agriculture and Livestock, and Cattle Breeders Association. All experiments were carried out in compliance with the ethical requirements and were approved by the local Ethics Committee for Animal Research (case no. 2010-08/06). The herd consisted of 168 purebred Holstein cows housed in three free-stall barns. All animals were fed the same diets and had full access to water throughout the experiment. All animals were milked three times per day at the time of sampling for the determination of STAT1, OLR1, CSN1S1, CSN1S2, and $D G A T 1$ genotypes. Milk yield of each animal was recorded daily in milking parlors equipped with electronic devices that automatically recorded the quantity of milk produced by every individual animal. Furthermore, lactation milk yield, 305 days milk yield, days before peak milk production, and peak milk yield were recorded separately. Daily milk yield (three times per day) and management records for each cow were collected in the Alpro 2000 system (DeLaval, Tumba, Sweden). The 305 days milk yield was calculated for each cow based on total milk yield (Lucy et al., 1993). In addition, milk samples were analysed monthly for fat, protein, lactose, and solid content with a Bentley 150 (Bentley Instruments Inc., Chaska, MN, USA) milk analyser. Milk fat yield, lactose yield, protein yield, and total milk solids were calculated based on the milk production levels obtained from the analysis. To calculate fat, lactose, protein yield, and total milk solids, the first milk control was performed five days after the beginning of lactation and monthly thereafter. The yields obtained in the first control was multiplied by the period between calving and first control. Further, the average of fat, lactose, protein yield, and total milk solids obtained in consecutive controls was multiplied by the number of days between controls to calculate the corresponding total yield. Days before peak milk production was determined individually as the period 
between the beginning of lactation and the day when a peak milk yield was achieved.

DNA for molecular analyses was extracted from $4 \mathrm{~mL}$ of peripheral blood samples that were collected in $\mathrm{K}_{3}$ EDTA tubes (Vacutest Kima, SRL, Italy) by using the phenol chloroform procedure, as described by Green and Sambrook (2012). The concentration range $(\mathrm{ng} / \mu \mathrm{L})$ and purity (absorbance at 260-280 nm) of the DNA samples were measured with a spectrophotometer (NanoDrop 2000c, Thermo Scientific, Wilmington, DE, USA). Genotypes of STAT1, OLR1, CSN1S1, CSN1S2, and DGAT1 genes were detected using a polymerase chain reaction and restriction fragment length polymorphism method (PCRRFLP) (Table 1). The PCR amplification was carried out in a total volume of $50 \mu \mathrm{L}$ containing $33.5 \mu \mathrm{L} \mathrm{ddH}_{2} \mathrm{O}, 5 \mu \mathrm{L}$ $10 \times$ buffer, $5 \mu \mathrm{L} \mathrm{MgSO}_{4}, 1 \mu \mathrm{L}$ dNTPs $(2.5 \mathrm{mM}), 2.5 \mathrm{U}$ Taq DNA polymerase (Biomatik, A1003-500 U, $5 \mathrm{U} / \mu \mathrm{L}$ ), $1 \mu \mathrm{L}(0.025 \mu \mathrm{M})$ of each primer, and $3 \mu \mathrm{L}$ of the DNA sample at a concentration of $100 \mathrm{ng} / \mu \mathrm{L}$. Afterwards, $15 \mu \mathrm{L}$ of the amplified product with each SNP was digested with $15 \mathrm{U}$ of the corresponding restriction enzyme (Table 2). Electrophoresis on agarose gel (Sigma Aldrich, Steinheim,
Germany) was used for visualisation of fragments in a gel imaging system (DNR-Minilumi, DNR Bio-Imaging Systems, Israel).

Indices of genetic diversity including gene heterozygosity $(\mathrm{He})$, effective allele numbers $(\mathrm{Ne})$, and polymorphism information content (PIC) were estimated as described by Nei and Roychoudhury (1974) and Botstein et al. (1980).

Statistical analyses were performed with the general linear model (GLM) procedure of Minitab (Minitab Inc., State College, PA, USA, version 17.1.0) to evaluate individual effects of each genotype. Levene's test was used to evaluate homogeneity of the variances. To achieve best subset through a proper statistical model, initially, sire effect was added to the model, but afterwards, this effect was excluded from the model because of a very large number of sires. The same implementation was performed for the effect of age of cow. In this context, the following optimal model was chosen by evaluating the adjusted $\mathrm{R}^{2}$ to compare the explanatory power of models with different numbers of predictors to determine possible significant differences between the genotypes:

Table 1 - Description of the single nucleotide polymorphisms (SNP) considered in this study

\begin{tabular}{|c|c|c|c|c|c|c|}
\hline Locus symbol & Chromosomal location & GenBank Acc. no. & SNP location & Position & Functional significance & Substitution \\
\hline$\overline{\text { STAT1 }}$ & 2 & AW289395 & 3'UTR & g. $3141 \mathrm{C}>\mathrm{T}$ & & $\mathrm{C} / \mathrm{T}$ \\
\hline OLR1 & 5 & NM_174132 & 3'UTR & g. $8232 \mathrm{C}>\mathrm{A}$ & & $\mathrm{C} / \mathrm{A}$ \\
\hline CSN1S1 & $6 \mathrm{q} 31$ & X59856 & Exon XVII & g. $17807 \mathrm{~A}>\mathrm{G}$ & E192G & $\mathrm{A} / \mathrm{G}$ \\
\hline CSNIS2 & $6 \mathrm{q} 31$ & M94327 & Exon VIII & g. $8879 \mathrm{G}>\mathrm{T}$ & & $\mathrm{G} / \mathrm{T}$ \\
\hline$D G A T 1$ & 14 & AY065621 & Exon VIII & $\begin{array}{l}\text { g. } 10433 \mathrm{G}>A \\
\text { g. } 10434 C>A\end{array}$ & $\mathrm{~K} 232 \mathrm{~A}^{1}$ & $\mathrm{AA} / \mathrm{GC}$ \\
\hline
\end{tabular}

STAT1 - signal transducer and activator of transcription 1; OLR1 - oxidized low-density lipoprotein receptor 1; CSN1S1 - alphaS1-casein; CSN1S2 - alphaS2-casein; DGAT1 diacylglycerol acyltransferase 1 .

${ }^{1}$ The two SNP in the DGATl gene lie immediately adjacent to one another in exon VIII, and the two alleles at this locus are AA and GC, encoding lysine (K) and alanine (A) at the amino acid position 232 .

Table 2 - Primer sequences (from 5' to 3'), PCR conditions, and restriction enzymes used for genotyping the polymorphisms in the current study

\begin{tabular}{|c|c|c|c|c|c|c|}
\hline Gene & Allele & $\begin{array}{l}\text { PCR amplicon } \\
\text { (bp) }\end{array}$ & Primer & PCR condition & $\begin{array}{c}\text { Restriction } \\
\text { enzyme }\end{array}$ & Reference \\
\hline$S T A T 1^{1}$ & $\mathrm{C} / \mathrm{T}$ & 314 & $\begin{array}{l}\text { F: 5'GCCTCAAGTTTGCCAGTGGC3' } \\
\text { R: 5'GGCTCCCTTGATAGAACTGT3' }\end{array}$ & $\begin{array}{c}95^{\circ} \mathrm{C} 5^{\prime}\left(94^{\circ} \mathrm{C} 45 \mathrm{~s}, 63^{\circ} \mathrm{C} \text { to } 50^{\circ} \mathrm{C},-2^{\circ} \mathrm{C}\right. \\
\left.\text { per cycle, } 45 \mathrm{~s}, 72^{\circ} \mathrm{C} 45 \mathrm{~s}\right) 32 \text { cycles, } \\
72^{\circ} \mathrm{C} 10^{\prime}\end{array}$ & $B s p H \mathrm{I}$ & $\begin{array}{l}\text { Rychtářová et al } \\
\qquad(2014)\end{array}$ \\
\hline OLR1 & $\mathrm{A} / \mathrm{C}$ & 143 & $\begin{array}{l}\text { F: 5'TCCCTAACTTGTTCCAAGTCCT3' } \\
\text { R: 5'CTCTACAATGCCTAGAAGAAAGC3' }\end{array}$ & $\begin{array}{c}94^{\circ} \mathrm{C} 5^{\prime}\left(94^{\circ} \mathrm{C} 30 \mathrm{~s}, 62^{\circ} \mathrm{C} 30 \mathrm{~s}, 72^{\circ} \mathrm{C} 40 \mathrm{~s}\right) \\
30 \text { cycles, } 72^{\circ} \mathrm{C} 5^{\prime}\end{array}$ & Pst $\mathrm{I}$ & $\begin{array}{l}\text { Komisarek and } \\
\text { Dorynek (2009) }\end{array}$ \\
\hline CSN1S1 & $\mathrm{B} / \mathrm{C}$ & 344 & $\begin{array}{l}\text { F: 5'ACAATTCTACCAGCTGGATGCCTATC3' } \\
\text { R: 5'CACGCTCCACAGTTCCTGAGTAA3' }\end{array}$ & $\begin{array}{c}94^{\circ} \mathrm{C} 3^{\prime}\left(94^{\circ} \mathrm{C} 30 \mathrm{~s}, 63^{\circ} \mathrm{C} 45 \mathrm{~s}, 72^{\circ} \mathrm{C} 1^{\prime}\right) \\
40 \text { cycles, } 72^{\circ} \mathrm{C} 10^{\prime}\end{array}$ & $H p h \mathrm{I}$ & $\begin{array}{l}\text { Kucerova et al. } \\
\text { (2006) }\end{array}$ \\
\hline CSN1S2 & $\mathrm{D} / \mathrm{A}$ & 356 & $\begin{array}{l}\text { F: 5'AAAACAAGCAGCCAAGAAGC3' } \\
\text { R: 5'TTCCCAGTCTCCCCAGTATG3' }\end{array}$ & $\begin{array}{c}94^{\circ} \mathrm{C} 2^{\prime}\left(94^{\circ} \mathrm{C} 30 \mathrm{~s}, 60.5^{\circ} \mathrm{C} 30 \mathrm{~s}, 72^{\circ} \mathrm{C} 1^{\prime}\right) \\
30 \text { cycles, } 72^{\circ} \mathrm{C} 10^{\prime}\end{array}$ & $M n l \mathrm{I}$ & $\begin{array}{l}\text { Ibeagha-Awemu } \\
\text { et al. (2007) }\end{array}$ \\
\hline$D G A T 1^{1}$ & $\mathrm{~A} / \mathrm{K}$ & 411 & $\begin{array}{l}\text { F: 5'GCACCATCCTCTTCCTCAAG3' } \\
\text { R: 5'GGAAGCGCTTTCGGATG3' }\end{array}$ & $\begin{array}{c}94^{\circ} \mathrm{C} 4^{\prime}, 10 \text { cycles }\left(94^{\circ} \mathrm{C} 60 \mathrm{~s}, 66^{\circ} \mathrm{C} 60 \mathrm{~s} ;\right. \\
\left.-1^{\circ} \mathrm{C} \text { per cycle, } 72^{\circ} \mathrm{C} 60 \mathrm{~s}\right), 25 \text { cycles } \\
\left(94^{\circ} \mathrm{C} 60 \mathrm{~s}, 56^{\circ} \mathrm{C} 120 \mathrm{~s}, 72^{\circ} \mathrm{C} 60 \mathrm{~s}\right) \\
72^{\circ} \mathrm{C} 15^{\prime}\end{array}$ & $C f r \mathrm{I}$ & $\begin{array}{l}\text { Lacorte et al. } \\
\quad(2006)\end{array}$ \\
\hline
\end{tabular}

PCR - polymerase chain reaction; STAT1 - signal transducer and activator of transcription 1; OLR1 - oxidized low-density lipoprotein receptor 1; CSN1S1 - alphaS1-casein; CSN1S2 alphaS2-casein; DGAT1 - diacylglycerol acyltransferase 1 .

${ }^{1}$ Touchdown PCR protocol was used. 


$$
\begin{aligned}
\mathrm{Y}_{\mathrm{ij} k \mathrm{mnnop}}=\mu+\mathrm{S}_{\mathrm{i}}+\mathrm{P}_{\mathrm{j}}+\mathrm{R}_{\mathrm{k}}+\mathrm{AG}_{1}+\mathrm{BG}_{\mathrm{m}}+\mathrm{CG}_{\mathrm{n}}+\mathrm{DG}_{\mathrm{o}}+\mathrm{EG}_{\mathrm{p}} \\
+\mathrm{e}_{\mathrm{ijklmnop}},
\end{aligned}
$$

in which $\mathrm{Y}_{\mathrm{ijklmnop}}=$ studied traits; $\mu=$ overall mean; $\mathrm{S}_{\mathrm{i}}=$ fixed effect of lactation season ( $\mathrm{i}=$ autumn, winter, spring, and summer); $P_{j}=$ fixed effect of service period $(j=\leq 50,51-80,81-110,111-140,140 \geq) ; R_{k}=$ fixed effect of lactation rank $(\mathrm{k}=1,2,3,4) ; \mathrm{AG}_{1}=$ fixed effect of the STAT1 genotype $(1=\mathrm{CC}, \mathrm{TC}, \mathrm{TT}) ; \mathrm{BG}_{\mathrm{m}}=$ fixed effect of the OLR1 genotype $(\mathrm{m}=\mathrm{AA}, \mathrm{AC}) ; \mathrm{CG}_{\mathrm{n}}=$ fixed effect of the CSN1S1 genotype $(\mathrm{n}=\mathrm{BB}, \mathrm{BC}) ; \mathrm{DG}_{\mathrm{o}}=$ fixed effect of the CSN1S2 genotype (o = DA, DD); $\mathrm{EG}_{\mathrm{p}}=$ fixed effect of the DGATl genotype $(\mathrm{p}=\mathrm{KA}, \mathrm{KK})$ and $\mathrm{e}_{\mathrm{ijklmnop}}=$ the random residual effect.

For all statistical comparisons, a probability level of $\mathrm{P}<0.05$ was accepted as statistically significant. When significant associations were identified, the mean values for each effect were contrasted using Tukey's test.

\section{Results}

We investigated five polymorphisms corresponding to STAT1, OLR1, CSN1S1, CSN1S2, and DGAT1. Results indicated that the population was not under HardyWeinberg Equilibrium (HWE) for the locus STAT1, OLR1, and DGAT1 $(\mathrm{P}<0.05)$. The minor allele frequencies (MAF) ranged from 0.01 to 0.48 (Table 3). Our results indicated that CSN1S1 and CSN1S2 markers showed high frequency of allele B (0.95) and D (0.99), respectively, and hence, only markers STAT1, OLR1, and DGAT1 were polymorphic. The CSN1S1 and CSN1S2 markers showed very low frequency of alleles $\mathrm{C}(0.05 \%)$ and $\mathrm{A}(0.01 \%)$, resulting in low genetic variabilities of $\mathrm{He}, \mathrm{Ne}$, and $\mathrm{PIC}$ compared with other markers showing relatively high values of $\mathrm{He}(0.4608-0.4992), \mathrm{Ne}(1.85-1.99)$, and PIC (0.3546-0.3746) (Table 3).
Non-significant differences among STAT1, OLR1, CSN1S1, CSN1S2, and DGAT1 genotypes were found for lactation milk yield, 305 days milk yield, and total milk components including fat, protein, lactose, and solids ( $\mathrm{P}>0.05)$ (Table 4).

Milk protein content was significantly different in the CSN1S2 genotypes in the current study $(\mathrm{P}<0.05)$ (Table 5). In this context, DD genotype was associated with higher protein contents compared with DA genotype. In addition, the results indicated that DGAT1 was significantly associated with maximum peak milk yield $(\mathrm{P}<0.05)$, and heterozygous genotype was associated with a higher peak milk yield compared to KK genotype (Table 6).

\section{Discussion}

This study reports the association between STAT1, OLR1, CSN1S1, CSN1S2, and DGAT1 variants and milk production traits in Holstein dairy cattle. These genes were chosen because of their involvement in the development of the mammary gland. The genes are also located in the region of QTL influencing milk yield and composition traits (Khatib et al., 2006; Banos et al., 2008; Khatib et al., 2009). The present results showed a deviation from HWE for the STAT1, OLR1, and DGAT1 polymorphisms in Holstein population. Deviations from HWE can indicate inbreeding, population stratification, and even problems in genotyping (Wigginton et al., 2005). It is worth noting that indirect selection for these loci from the selection of milk production traits in Holstein may be another explanation for the mentioned disequilibrium. Polymorphism information content value is commonly used in genetic studies as a measure of polymorphism for a marker locus and suggests the quality of a marker (Nei and Roychoudhury, 1974; Shete et al., 2000). In this respect, a marker with a PIC value lower than 0.25 is considered low or not informative,

Table 3 - Allele and genotype frequencies of polymorphisms in STAT1, OLR1, CSN1S1, CSN1S2, and DGAT1 genes, population genetic

\begin{tabular}{|c|c|c|c|c|c|c|c|c|c|c|c|c|c|c|c|}
\hline SNP & & STAT1 & & & OLR1 & & & CSN1S1 & & & CSN1S2 & & & DGAT1 & \\
\hline Genotype & $\mathrm{CC}$ & $\mathrm{CT}$ & $\mathrm{TT}$ & AA & $\mathrm{AC}$ & $\mathrm{CC}$ & BB & $\mathrm{BC}$ & $\mathrm{CC}$ & $\mathrm{DD}$ & $\mathrm{DA}$ & AA & $\mathrm{AA}$ & KA & $\mathrm{KK}$ \\
\hline $\mathrm{N}$ & 76 & 61 & 31 & 46 & 122 & 0 & 152 & 16 & 0 & 164 & 4 & 0 & 0 & 161 & 7 \\
\hline$\%$ & 45.24 & 36.31 & 18.45 & 27.38 & 72.62 & 0 & 90.48 & 9.52 & 0 & 97.62 & 2.38 & 0 & 0 & 95.83 & 4.17 \\
\hline MAF & & 0.37 & & & 0.36 & & & 0.05 & & & 0.01 & & & 0.48 & \\
\hline $\mathrm{He}$ & & 0.4662 & & & 0.4608 & & & 0.0950 & & & 0.0198 & & & 0.4992 & \\
\hline $\mathrm{Ne}$ & & 1.87 & & & 1.85 & & & 1.10 & & & 1.02 & & & 1.99 & \\
\hline PIC & & 0.3576 & & & 0.3546 & & & 0.0905 & & & 0.0196 & & & 0.3746 & \\
\hline$\chi^{2}(\mathrm{HWE})$ & & 7.97 & & & 54.61 & & & 0.42 & & & 0.02 & & & 142.19 & \\
\hline $\mathrm{P}$ & & $0.004 *$ & & & $0.000^{* *}$ & & & 0.52 & & & 0.88 & & & $0.000^{* *}$ & \\
\hline
\end{tabular}
indices (He, Ne, PIC), and compatibility with the Hardy-Weinberg equilibrium

$\chi^{2}(\mathrm{HWE})$ - Hardy-Weinberg equilibrium $\chi^{2}$ value; $\mathrm{N}$ - number of experimental cows; MAF - minor allele frequency; He - heterozygosity; Ne - effective allele number; PIC polymorphism information content.

$* \mathrm{P}<0.05$ and $* * \mathrm{P}<0.001$ - not consistent with HWE. 
Table 4 - Levels of significance, least squares means, and standard errors for the effect of STAT1, OLR1, CSN1S1, CSN1S2 and DGAT1 on milk yield traits in Holstein cows

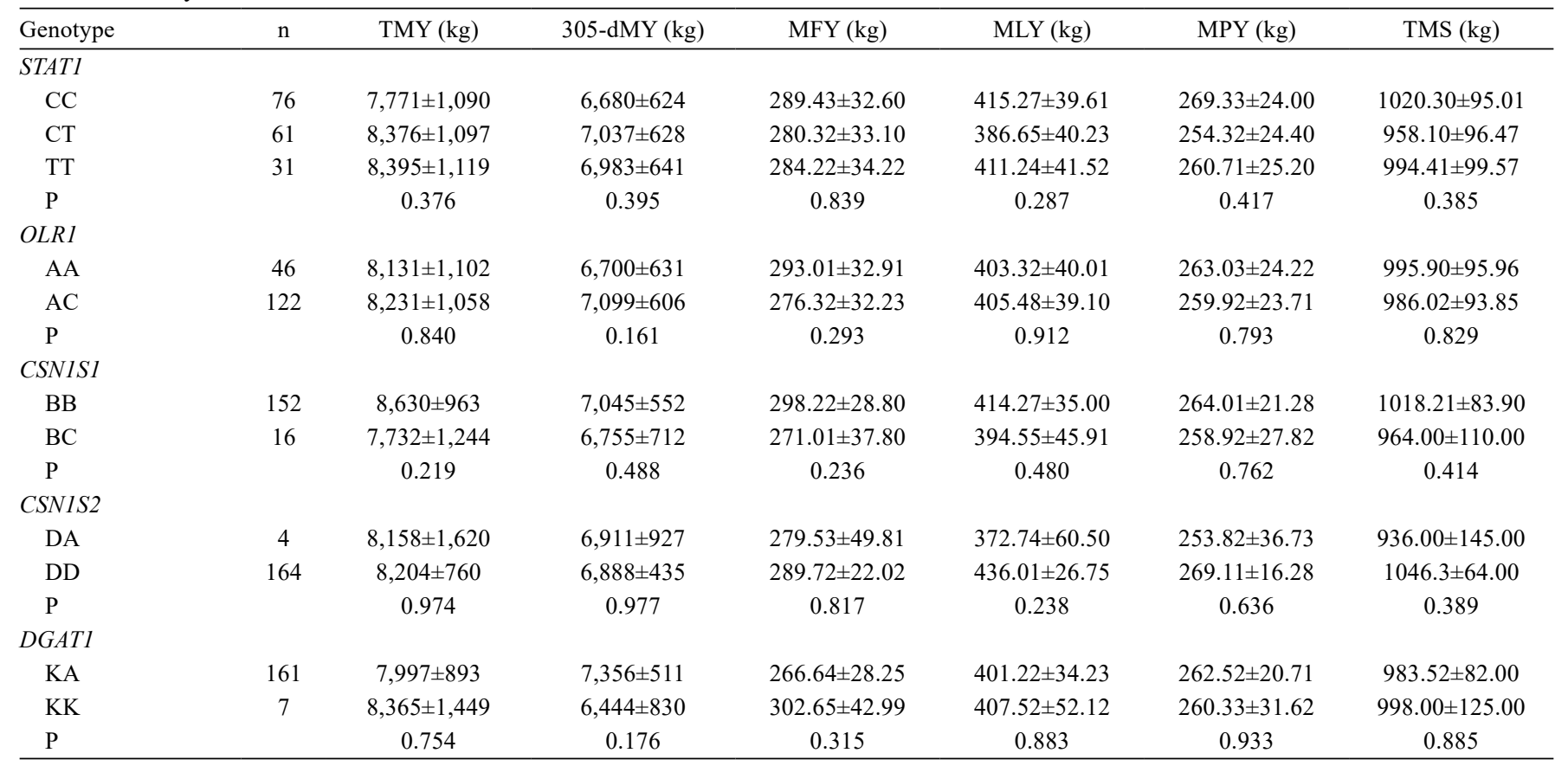

TMY - total milk yield; 305-dMY - 305-day milk yield; MFY - milk fat yield; MLY - milk lactose yield; MPY - milk protein yield; TMS - total milk solids.

Table 5 - Levels of significance, least squares means, and standard errors for the effect of STAT1, OLR1, CSN1S1, CSN1S2, and DGAT1 on milk content and peak milk production traits in Holstein cows

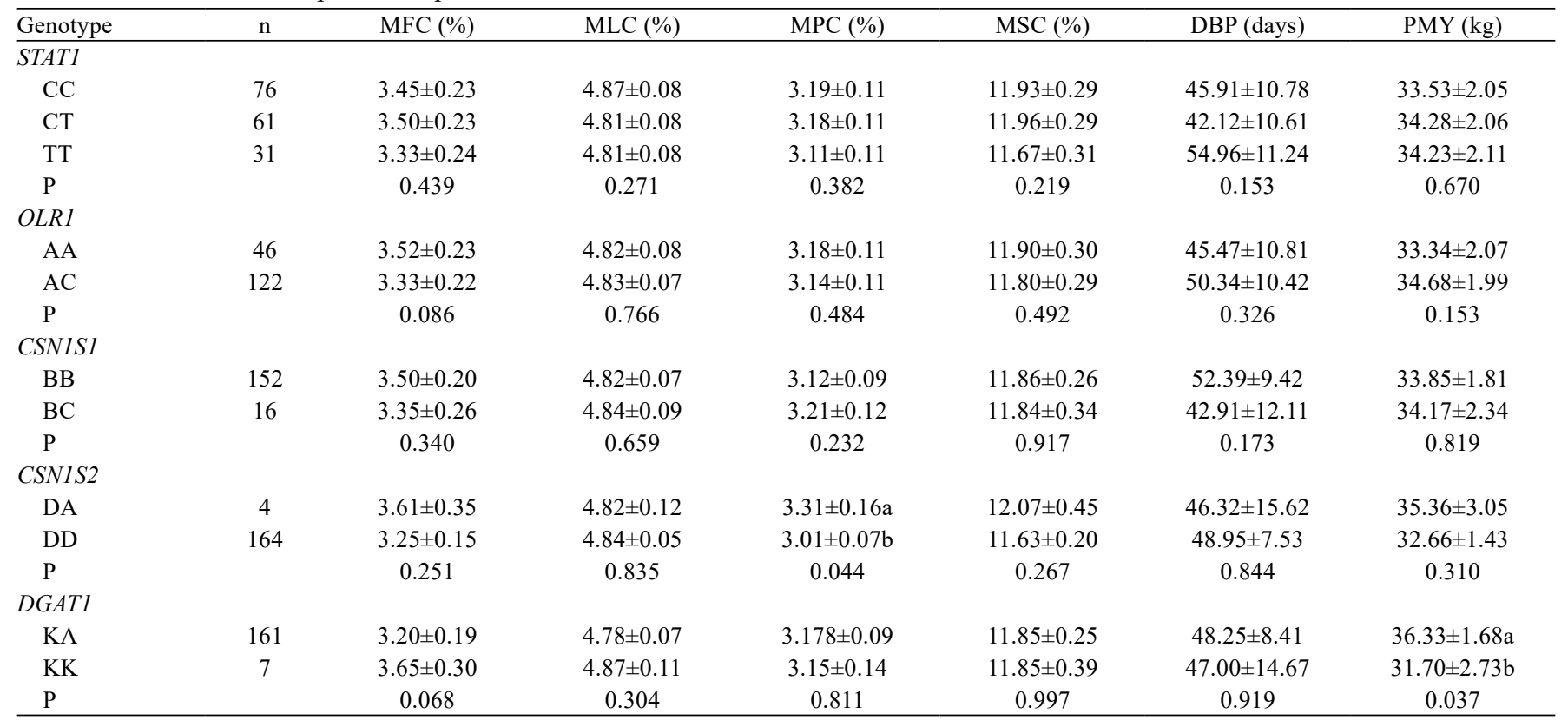

MFC - milk fat content; MLC - milk lactose content; MPC - milk protein content; MSC - milk solid content; DBP - days before peak milk production; PY - peak milk yield. a,b - Different letters within a column indicate significant difference $(\mathrm{P}<0.05)$.

whereas values between 0.25 and 0.5 are mildly informative. Markers with PIC values of 0.5 or higher are highly informative for genetic studies and are extremely useful in distinguishing the polymorphism rate of a marker at a specific locus (Botstein et al., 1980). According to this classification, markers used in the present study were mildly informative, except for CSN1S1 and CSN1S2. The reason may be due to very low frequency of minor alleles for both polymorphisms; a similar interpretation can be given to gene heterozygosity. In this case, low heterozygosity values could be explained by high level of inbreeding or high selection pressure. 
Table 6 - Variance components (percentages) estimated in the present study

\begin{tabular}{|c|c|c|c|c|c|}
\hline \multirow{2}{*}{ Traits } & \multicolumn{5}{|c|}{ Genetic markers } \\
\hline & STAT1 & OLR1 & CSN1S1 & $C S N 1 S 2$ & DGAT1 \\
\hline 305-dMY & $802.445(0.03 \%)$ & $38660.5(1.55 \%)$ & $-38205.8(0 \%)$ & $-319713(0 \%)$ & $191921(7.71 \%)$ \\
\hline MLY & $73.8357(0.68 \%)$ & $-174.415(0 \%)$ & $-120.946(0 \%)$ & $920.128(8.43 \%)$ & $-917.171(0 \%)$ \\
\hline MPY & $-10.7015(0 \%)$ & $-56.113(0 \%)$ & $-119.251(0 \%)$ & $-366.285(0 \%)$ & $-339.271(0 \%)$ \\
\hline TMS & $-16.7618(0 \%)$ & $-887.28(0 \%)$ & $-258.516(0 \%)$ & $-560.515(0 \%)$ & $-5303.04(0 \%)$ \\
\hline MLC & $0.00013(0.32 \%)$ & $-0.00069(0 \%)$ & $-0.00138(0 \%)$ & $-0.00545(0 \%)$ & $0.00019(0.46 \%)$ \\
\hline MPC & $0.00052(0.17 \%)$ & $-0.00091(0 \%)$ & $0.00195(1.76 \%)$ & $0.03607(32.53 \%)^{*}$ & $-0.00621(0 \%)$ \\
\hline MSC & $0.00357(0.63 \%)$ & $-0.00533(0 \%)$ & $-0.02042(0 \%)$ & $0.01293(2.29 \%)$ & $-0.04949(0 \%)$ \\
\hline DBP & $219.091(4.63 \%)$ & $110.699(2.34 \%)$ & $733.387(15.50 \%)$ & $934.381(19.75 \%)$ & $-258.712(0 \%)$ \\
\hline PMY & $-0.31986(0 \%)$ & $0.56867(1.70 \%)$ & $-0.86174(0 \%)$ & $0.34154(1.02 \%)$ & $8.2674(24.68 \%)^{*}$ \\
\hline
\end{tabular}

TMY - total milk yield; 305-dMY - 305 day milk yield; MFY - milk fat yield; MLY - milk lactose yield; MPY - milk protein yield; TMS - total milk solids; MFC - milk fat content; MLC - milk lactose content; MPC - milk protein content; MSC - milk solid content; DBP - days before peak milk production; PMY - peak milk yield. $* \mathrm{P}<0.05$.

The expression of STAT1 gene is under the control of prolactin hormone. The binding of prolactin to its receptor initiates the activation of the STAT1, STAT3, and STAT5 proteins that regulate genes related to milk proteins and components (Bole-Feysot et al., 1998). Several studies have indicated that STAT1 is significantly associated with production traits (Ashwell et al., 1997; Mosig et al., 2001; Ron et al., 2004). Rychtářová et al. (2014) reported that genotypes CC and CT were associated with significant increases in milk protein percentage. Significant differences were also observed between the mentioned genotypes in estimated breeding value for protein percentage and fat percentage. However, results from this study showed, conversely, that there was no association between the STAT1 marker and milk yield and components.

The animal breed, environmental factors, and production procedures determine milk-related traits (Butler et al., 1981; Palmquist et al., 1993). The population substructure, presence of null alleles or high selection pressure, and inbreeding or indirect selection for these loci in the Holstein breed should be taken into account in association studies (Lacorte et al., 2006). The inconsistency between our findings and results of previous studies may be attributable, at least in part, to the above-mentioned circumstances. Hence, further genetic studies investigating STAT1 marker need to be performed with larger populations before using them in marker-assisted selection. It is worth noting that milk production traits, which are under the control of polygenic inheritance, may vary between breeds and even between different populations of the same breed (Braunschweig et al., 2000; Boettcher et al., 2004). In addition, evaluating non-allelic interactions and linkage should be considered to perform an adequate association analysis (Boettcher et al., 2004). Inconsistent results are not surprising for the mentioned reasons.

Many QTL related to milk yield and quality were mapped on the bovine chromosome 5 , near the location of the OLR1 gene (Koning et al., 2001; Olsen et al., 2002; Rychtářová et al., 2014). However, marker C223A, an SNP at the 3' untranslated region of the bovine OLR1 gene, was not associated with either milk yield or composition traits in this study. Similarly, Rychtářová et al. (2014) also found no significant association between the OLRI C223A marker and any of the milk production traits or reproduction traits in the Czech Fleckvieh population. Conversely, Khatib et al. (2006) reported an association of this marker with milk fat percentage and milk fat yield in a population of the North American Holstein cattle. Schennink et al. (2009) reported that OLR1 C223A had a significant effect on milk fat percentage in HolsteinFriesian cattle. OLR1 gene contributes to the balance of oxidised low-density lipoproteins, which affect glucose and lipid metabolism in the mammary gland (Khatib et al., 2006; Schennink et al., 2009; Rychtáŕová et al., 2014). In addition, bovine chromosome 5, in which the OLR1 gene is located, has been shown to be associated with milk fat content (Khatib et al., 2006; Rychtáŕová et al., 2014). However, inconsistent results are found in the literature; moreover, there is insufficient information that outlines the association of OLRI C223A marker with milk production traits. Further studies are needed to confirm the present results and to observe novel associations.

Our results suggested that the CSNIS1 locus was not associated with any of the traits analysed in this study. Kucerova et al. (2006) reported a significant association 
of CSN1S1 with milk yield. Van Eenennaam and Medrano (1991) also found that protein content and milk yield were different between the CSN1S1 genotypes. In addition, Boettcher et al. (2004) suggested a significant association between $C N$ haplotypes and production traits of Italian Holstein and Brown Swiss. The reason for the lack of a correlation in our study may be due to genetic constitution of the population and the highly unbalanced genotype distribution. Hence, it is difficult to evaluate the genotypic associations for the CSN1S1 locus. A significant effect of CSN1S2 locus was found only on milk protein content in the present study. Heterozygous genotype was associated with higher protein content compared with DD genotype. However, it is worth noting that the frequency of DA genotype was rather low (2.38\%). Moreover, AA genotype was absent in the present study. Further studies should be carried out to perform an adequate evaluation.

Caseins are a family of phosphoproteins that comprise the major protein component of ruminant milk (Corral et al., 2013) and are functionally regulated by $C N$ genes (Caroli et al., 2009). The $C N$ gene family, including CSN1S1 and CSN1S2, is located on bovine chromosome 6, which is associated with milk components and milk quality (Boettcher et al., 2004; Kucerova et al., 2006; Caroli et al., 2009). Focusing on novel associations and characterisation of CSN1S2 locus may be highly relevant for elucidating the influence of this genomic region on observed milk production traits.

Many studies in dairy cattle have shown that a QTL with a major influence on milk production is located on bovine chromosome 14 (Coppieters et al., 1998; Looft et al., 2001; Farnir et al., 2002), and the DGAT1 gene is located at this genomic region (Grisart et al., 2002; Winter et al., 2002). Polymorphism of K232A in exon 8 of the DGAT1 gene has been associated with milk yield (Spelman et al., 2002; Kaupe et al., 2007; Kuehn et al., 2007; Szyda and Komisarek, 2007; Banos et al., 2008; Berry et al., 2010), fat yield (Berry et al., 2010) and content (Spelman et al., 2002; Kaupe et al., 2007; Kuehn et al., 2007; Szyda and Komisarek, 2007), and protein content (Grisart et al., 2002; Spelman et al., 2002; Thaller et al., 2003a; Kaupe et al., 2007; Berry et al., 2010). In the current study, DGAT1 K232A marker did not have any significant effect on the mentioned traits. However, a novel association between this marker and peak milk production was observed $(\mathrm{P}<0.05)$. Animals with KA genotype had $+4.63 \mathrm{~kg}$ higher milk yield in peak compared with KK animals. Berry et al. (2010) reported that $\mathrm{K}$ allele was associated with decreased milk yield in Holstein-Friesian cattle. Previous studies focused on the effect of the DGAT1 locus on milk production traits in various cattle populations. However, information about the association of this locus with peak milk production is insufficient. Economically, the configuration of the lactation curve and details about the position and duration of peak yield are important in dairy cattle (Wood, 1967). Hence, genotypic information and novel associations that influence the lactation curve and peak milk production may be useful in improving milk production traits.

In the literature, STAT1, OLR1, CSN1S1, CSN1S2, and DGAT1 genes were found to be effective in milk production traits (Boettcher et al., 2004; Kaupe et al., 2007; Khatib et al., 2006; Rychtářová et al., 2014). Two aspects have been commonly used for analysing the relation between individual and combined genotypic effects and milk production parameters. Some studies reported the association between genotypes and phenotypes of cows, while other studies evaluated the possible associations by using data from sires and determining their breeding values (Kucerova et al., 2006). In the current study, non-significant differences $(\mathrm{P}>0.05)$ among STAT1, OLR1, CSN1S1, CSN1S2, and DGAT1 genotypes were found for lactation milk yield, 305 days milk yield, total milk components (including fat, protein, lactose, and solids), lactose and solid content, and days before peak milk production in Holstein cows. The CSN1S2 and DGAT1 markers significantly affected protein content and peak milk production, respectively $(\mathrm{P}<0.05)$. However, further results from studies for larger populations might be useful to draw more reliable conclusions and to perform an adequate evaluation.

\section{Conclusions}

Milk protein content is significantly different between the CSN1S2 genotypes in Holstein cows. Moreover, results indicated a novel effect of the DGAT1 K232A marker on peak milk production. Such genotypic information may have potential for management systems in dairy cattle, but it should be confirmed in larger populations. Thus, a selection of animals with the favourable single nucleotide polymorphisms genotypes may result in animals with higher milk yield and protein content.

\section{Acknowledgments}

The authors would like to thank Matli Incorporated Company, for their help in managing the animals and collecting blood samples. This research was supported by the Uludag University Scientific Research Projects Funds (Grant No: UAPV-2011/21). The language assistance of I. Taci Cangul is appreciated. 


\section{References}

Ashwell, M. S.; Rexroad, C. E.; Miller, R.; VanRaden, P. M. and Da, Y. 1997. Detection of loci affecting milk production and health traits in an elite US Holstein population using microsatellite markers. Animal Genetics 28:216-222. https://doi.org/10.1111/ j.1365-2052.1997.00115.x

Band, M. R.; Larson, J. H.; Rebeiz, M.; Green, C. A.; Heyen, D. W.; Donovan, J.; Windish, R.; Steining, C.; Mahyuddin, P. and Womack, J. E. 2000. An ordered comparative map of the cattle and human genomes. Genome research 10:1359-1368. https://doi. org/10.1101/gr.145900

Banos, G.; Woolliams, J.; Woodward, B.; Forbes, A. and Coffey, M. 2008. Impact of single nucleotide polymorphisms in leptin, leptin receptor, growth hormone receptor, and diacylglycerol acyltransferase (DGAT1) gene loci on milk production, feed, and body energy traits of UK dairy cows. Journal of Dairy Science 91:3190-3200. https://doi.org/10.3168/jds.2007-0930

Berry, D. P.; Howard, D.; O’Boyle, P.; Waters, S.; Kearney, J. and McCabe, M. 2010. Associations between the K232A polymorphism in the diacylglycerol-O-transferase 1 (DGAT1) gene and performance in Irish Holstein-Friesian dairy cattle. Irish Journal of Agricultural and Food Research 49:1-9.

Boettcher, P.; Caroli, A.; Stella, A.; Chessa, S.; Budelli, E.; Canavesi, F.; Ghiroldi, S. and Pagnacco, G. 2004. Effects of casein haplotypes on milk production traits in Italian Holstein and Brown Swiss cattle. Journal of Dairy Science 87:4311-4317. https://doi.org/10.3168/jds.S0022-0302(04)73576-6

Bole-Feysot, C.; Goffin, V.; Edery, M.; Binart, N. and Kelly, P. A. 1998. Prolactin (PRL) and its receptor: actions, signal transduction pathways and phenotypes observed in PRL receptor knockout mice. Endocrine Reviews 19:225-268. https://doi.org/10.1210/edrv.19.3.0334

Botstein, D.; White, R. L.; Skolnick, M. and Davis, R. W. 1980. Construction of a genetic linkage map in man using restriction fragment length polymorphisms. American Journal of Human Genetics 32:314-331.

Braunschweig, M.; Hagger, C.; Stranzinger, G. and Puhan, Z. 2000. Associations between casein haplotypes and milk production traits of Swiss brown cattle. Journal of Dairy Science 83:1387-1395. https://doi.org/10.3168/jds.S0022-0302(00)75007-7

Butler, W.; Everett, R. and Coppock, C. 1981. The relationships between energy balance, milk production and ovulation in postpartum Holstein cows. Journal of Animal Science 53:742-748. https://doi.org/10.2527/jas1981.533742x

Caroli, A.; Chessa, S. and Erhardt, G. 2009. Invited review: Milk protein polymorphisms in cattle: Effect on animal breeding and human nutrition. Journal of Dairy Science 92:5335-5352. https://doi.org/10.3168/jds.2009-2461

Cerit, H.; Dumen, E. and Sezgin, F. H. 2014. Comparison of DGAT1 K232a polymorphism and its effects on some milk quality parameters in Holstein and native black race cattles. Journal of the Faculty of Veterinary Medicine Kafkas University 20:301-305.

Chu, M. and Zan, L. S. 2009. Association between polymorphism of STAT1 gene and milk production traits in Chinese Holstein Cattle. Chinese Journal of Animal and Veterinary Sciences 40:309-314.

Coppieters, W.; Riquet, J.; Arranz, J.-J.; Berzi, P.; Cambisano, N.; Grisart, B.; Karim, L.; Marcq, F.; Moreau, L. and Nezer, C. 1998. A QTL with major effect on milk yield and composition maps to bovine chromosome 14. Mammalian Genome 9:540-544. https://doi.org/10.1007/s003359900815

Corral, J.; Padilla, J.; Izquierdo, M.; Martínez-Trancón, M.; Parejo, J.; Salazar, J. and Hernández-García, F. 2013. Detection and genetic characterization of ovine CSN1S2*B polymorphisms and their associations with milk production traits. Livestock Science 153:10-19. https://doi.org/10.1016/j.livsci.2013.01.008
Farnir, F.; Grisart, B.; Coppieters, W.; Riquet, J.; Berzi, P.; Cambisano, N.; Karim, L.; Mni, M.; Moisio, S. and Simon, P. 2002. Simultaneous mining of linkage and linkage disequilibrium to fine map quantitative trait loci in outbred half-sib pedigrees: revisiting the location of a quantitative trait locus with major effect on milk production on bovine chromosome 14. Genetics 161:275-287.

Green, M. and Sambrook, J. 2012. Isolation and quantification of DNA. Molecular Cloning: A Laboratory Manual 1:11-80.

Grisart, B.; Coppieters, W.; Farnir, F.; Karim, L.; Ford, C.; Berzi, P.; Cambisano, N.; Mni, M.; Reid, S. and Simon, P. 2002. Positional candidate cloning of a QTL in dairy cattle: identification of a missense mutation in the bovine DGAT1 gene with major effect on milk yield and composition. Genome Research 12:222-231. https://doi.org/10.1101/gr.224202

Grosclaude, F.; Joudrier, P. and Mahe, M. 1979. A genetic and biochemical analysis of a polymorphism of bovine $\alpha \mathrm{S} 2$-casein. Journal of Dairy Research 46:211-213. https://doi.org/10.1017/ S0022029900017052

Hradecká, E.; Citek, J.; Panicke, L.; Rehout, V. and Hanusova, L. 2008. The relation of GH1, GHR and DGAT1 polymorphisms with estimated breeding values for milk production traits of German Holstein sires. Czech Journal of Animal Science 53:238-245. https://doi.org/10.17221/362-CJAS

Ibeagha-Awemu, E.; Prinzenberg, E. M.; Jann, O.; Lühken, G.; Ibeagha, A.; Zhao, X. and Erhardt, G. 2007. Molecular characterization of bovine CSN1S2* B and extensive distribution of zebu-specific milk protein alleles in European cattle. Journal of Dairy Science 90:3522-3529. https://doi.org/10.3168/jds.2006-679

Kaupe, B.; Brandt, H.; Prinzenberg, E. and Erhardt, G. 2007. Joint analysis of the influence of CYP11B1 and DGAT1 genetic variation on milk production, somatic cell score, conformation, reproduction, and productive lifespan in German Holstein cattle. Journal of Animal Science 85:11-21. https://doi.org/10.2527/jas.2005-753

Khatib, H.; Leonard, S.; Schutzkus, V.; Luo, W. and Chang, Y. 2006. Association of the OLR 1 gene with milk composition in Holstein dairy cattle. Journal of Dairy Science 89:1753-1760. https://doi.org/10.3168/jds.S0022-0302(06)72243-3

Khatib, H.; Rosa, G.; Weigel, K.; Schiavini, F.; Santus, E. and Bagnato, A. 2007. Additional support for an association between OLR1 and milk fat traits in cattle. Animal Genetics 38:308-310. https://doi.org/10.1111/j.1365-2052.2007.01584.x

Khatib, H.; Huang, W.; Mikheil, D.; Schutzkus, V. and Monson, R. 2009. Effects of signal transducer and activator of transcription (STAT) genes STAT1 and STAT3 genotypic combinations on fertilization and embryonic survival rates in Holstein cattle. Journal of Dairy Science 92:6186-6191. https://doi.org/10.3168/jds.2009-2439

Komisarek, J. and Dorynek, Z. 2009. Effect of ABCG2, PPARGC1A, OLR1 and SCD1 gene polymorphism on estimated breeding values for functional and production traits in Polish HolsteinFriesian bulls. Journal of Applied Genetics 50:125-132. https://doi.org/10.1007/BF03195663

Kong, H.; Oh, J.; Lee, J.; Yoon, D.; Choi, Y.; Cho, B.; Lee, H. and Jeon, G. 2007. Association of sequence variations in DGAT 1 gene with economic traits in Hanwoo (Korea cattle). Asian-Australasian Journal of Animal Sciences 20:817-820. https://doi.org/10.5713/ ajas. 2007.817

Koning, D. J.; Schulmant, N.; Elo, K.; Moisio, S.; Kinos, R.; Vilkki, J. and Mäki-Tanila, A. 2001. Mapping of multiple quantitative trait loci by simple regression in half-sib designs. Journal of Animal Science 79:616-622. https://doi.org/10.2527/2001.793616x

Kucerova, J.; Matejicek, A.; Jandurova, O.; Sorensen, P.; Nemcova, E.; Stipkova, M.; Kott, T.; Bouska, J. and Frelich, J. 2006. Milk protein genes CSN1S1, CSN2, CSN3, LGB and their relation to genetic values of milk production parameters in Czech Fleckvieh. Czech Journal of Animal Science 51:241-247. https://doi.org/ 10.17221/3935-CJAS 
Kuehn, C.; Edel, C.; Weikard, R. and Thaller, G. 2007. Dominance and parent-of-origin effects of coding and non-coding alleles at the acylCoA-diacylglycerol-acyltransferase (DGAT1) gene on milk production traits in German Holstein cows. BMC Genetics 8:62-70. https://doi.org/10.1186/1471-2156-8-62

Lacorte, G.; Machado, M.; Martinez, M.; Campos, A.; Maciel, R.; Verneque, R.; Teodoro, R.; Peixoto, M.; Carvalho, M. and Fonseca, C. 2006. DGAT1 K232A polymorphism in Brazilian cattle breeds. Genetics and Molecular Research 5:475-482.

Li, X.; Ekerljung, M.; Lundström, K. and Lunden, A. 2013. Association of polymorphisms at DGAT1, leptin, SCD1, CAPN1 and CAST genes with color, marbling and water holding capacity in meat from beef cattle populations in Sweden. Meat Science 94:153-158. https://doi.org/10.1016/j.meatsci.2013.01.010

Liao, C. H.; Shaw, H. M. and Chao, P. M. 2008. Impairment of glucose metabolism in mice induced by dietary oxidized frying oil is different from that induced by conjugated linoleic acid. Nutrition 24:744-752. https://doi.org/10.1016/j.nut.2008.03.010

Looft, C.; Reinsch, N.; Karall-Albrecht, C.; Paul, S.; Brink, M.; Thomsen, H.; Brockmann, G.; Kuhn, C.; Schwerin, M. and Kalm, E. 2001. A mammary gland EST showing linkage disequilibrium to a milk production QTL on bovine Chromosome 14. Mammalian Genome 12:646-650. https://doi.org/10.1007/ s003350020003

Lucy, M.; Hauser, S.; Eppard, P.; Krivi, G.; Clark, J.; Bauman, D. and Collier, R. 1993. Variants of somatotropin in cattle: gene frequencies in major dairy breeds and associated milk production. Domestic Animal Endocrinology 10:325-333. https://doi.org/ 10.1016/0739-7240(93)90036-B

Mehta, J. L. and Li, D. 2002. Identification, regulation and function of a novel lectin-like oxidized low-density lipoprotein receptor. Journal of the American College of Cardiology 39:1429-1435. https://doi.org/10.1016/S0735-1097(02)01803-X

Mosig, M. O.; Lipkin, E.; Khutoreskaya, G.; Tchourzyna, E.; Soller, M. and Friedmann, A. 2001. A whole genome scan for quantitative trait loci affecting milk protein percentage in Israeli-Holstein cattle, by means of selective milk DNA pooling in a daughter design, using an adjusted false discovery rate criterion. Genetics 157:1683-1698.

Nei, M. and Roychoudhury, A. 1974. Sampling variances of heterozygosity and genetic distance. Genetics 76:379-390.

Oikonomou, G.; Angelopoulou, K.; Arsenos, G.; Zygoyiannis, D. and Banos, G. 2009. The effects of polymorphisms in the DGAT1, leptin and growth hormone receptor gene loci on body energy, blood metabolic and reproductive traits of Holstein cows. Animal Genetics 40:10-17. https://doi.org/10.1111/j.13652052.2008.01789.x

Olsen, H.; Gomez-Raya, L.; Vage, D.; Olsaker, I.; Klungland, H.; Svendsen, M.; Adnoy, T.; Sabry, A.; Klemetsdal, G. and Schulman, N. 2002. A genome scan for quantitative trait loci affecting milk production in Norwegian dairy cattle. Journal of Dairy Science 85:3124-3130. https://doi.org/10.3168/jds.S00220302(02)74400-7

Palmquist, D.; Beaulieu, A. D. and Barbano, D. 1993. Feed and animal factors influencing milk fat composition. Journal of Dairy Science 76:1753-1771. https://doi.org/10.3168/jds.S00220302(93)77508-6

Ringseis, R.; Dathe, C.; Muschick, A.; Brandsch, C. and Eder, K. 2007. Oxidized fat reduces milk triacylglycerol concentrations by inhibiting gene expression of lipoprotein lipase and fatty acid transporters in the mammary gland of rats. The Journal of Nutrition 137:2056-2061. https://doi.org/10.1093/jn/137.9.2056

Ron, M.; Feldmesser, E.; Golik, M.; Tager-Cohen, I.; Kliger, D.; Reiss, V.; Domochovsky, R.; Alus, O.; Seroussi, E. and Ezra, E. 2004.
A complete genome scan of the Israeli Holstein population for quantitative trait loci by a daughter design. Journal of Dairy Science 87:476-490. https://doi.org/10.3168/jds.S0022-0302(04)73187-2

Rychtářová, J.; Sztankóová, Z.; Kyselová, J.; Zink, V.; Štípková, M.; Vacek, M. and Štolc, L. 2014. Effect of DGAT1, BTN1A1, OLR1, and STAT1 genes on milk production and reproduction traits in the Czech Fleckvieh breed. Czech Journal of Animal Science 59:45-53. https://doi.org/10.17221/7228-CJAS

Schennink, A.; Bovenhuis, H.; Leon-Kloosterziel, K. M.; Van Arendonk, J. A. and Visker, M. H. 2009. Effect of polymorphisms in the FASN, OLR1, PPARGC1A, PRL and STAT5A genes on bovine milk-fat composition. Animal Genetics 40:909-916. https://doi.org/10.1111/j.1365-2052.2009.01940.x

Schennink, A.; Stoop, W. M.; Visker, M. W.; Heck, J. M.; Bovenhuis, H.; Poel, J. J.; Van Valenberg, H. J. and Van Arendonk, J. A. 2007. DGAT1 underlies large genetic variation in milk-fat composition of dairy cows. Animal Genetics 38:467-473. https://doi.org/10.1111/ j.1365-2052.2007.01635.x

Shete, S.; Tiwari, H. and Elston, R. C. 2000. On estimating the heterozygosity and polymorphism information content value. Theoretical population biology 57:265-271. https://doi.org/ 10.1006/tpbi.2000.1452

Spelman, R.; Ford, C.; McElhinney, P.; Gregory, G. and Snell, R. 2002. Characterization of the DGAT1 gene in the New Zealand dairy population. Journal of Dairy Science 85:3514-3517. https://doi.org/10.3168/jds.S0022-0302(02)74440-8

Szyda, J. and Komisarek, J. 2007. Statistical modeling of candidate gene effects on milk production traits in dairy cattle. Journal of Dairy Science 90:2971-2979. https://doi.org/10.3168/jds.2006-724

Tait, R.; Shackelford, S.; Wheeler, T.; King, D.; Keele, J.; Casas, E.; Smith, T. and Bennett, G. 2014. CAPN1, CAST, and DGAT1 genetic effects on preweaning performance, carcass quality traits, and residual variance of tenderness in a beef cattle population selected for haplotype and allele equalization. Journal of Animal Science 92:5382-5393. https://doi.org/10.2527/jas.2014-8211

Thaller, G.; Krämer, W.; Winter, A.; Kaupe, B.; Erhardt, G. and Fries, R. 2003a. Effects of variants on milk production traits in German cattle breeds. Journal of Animal Science 81:1911-1918. https://doi.org/10.2527/2003.8181911x

Thaller, G.; Kühn, C.; Winter, A.; Ewald, G.; Bellmann, O.; Wegner, J.; Zühlke, H. and Fries, R. 2003b. DGAT1, a new positional and functional candidate gene for intramuscular fat deposition in cattle. Animal Genetics 34:354-357. https://doi.org/10.1046/ j.1365-2052.2003.01011.x

Turkish Statistical Institute (TSI). 2018. Livestock statistics. Available at: <http://www.turkstat.gov.tr>. Accessed on: Feb. 26, 2018.

Van Eenennaam, A. and Medrano, J. F. 1991. Milk protein polymorphisms in California dairy cattle. Journal of Dairy Science 74:1730-1742. https://doi.org/10.3168/jds.S0022-0302(91)78336-7

Wigginton, J. E.; Cutler, D. J. and Abecasis, G. R. 2005. A note on exact tests of Hardy-Weinberg equilibrium. The American Journal of Human Genetics 76:887-893. https://doi.org/10.1086/429864

Winter, A.; Kramer, W.; Werner, F. A.; Kollers, S.; Kata, S.; Durstewitz, G.; Buitkamp, J.; Womack, J. E.; Thaller, G. and Fries, R. 2002. Association of a lysine-232/alanine polymorphism in a bovine gene encoding acyl-CoA: diacylglycerol acyltransferase (DGAT1) with variation at a quantitative trait locus for milk fat content. p.9300-9305. In: Proceedings of the National Academy of Sciences. United States of America.

Wood, P. 1967. Algebraic model of the lactation curve in cattle. Nature 216:164-165. https://doi.org/10.1038/216164a0 